\title{
Effect of Clozapine Treatment on Serotonin-2-Receptor Binding in the Blood Platelets of Schizophrenic Patients
}

\author{
Ramesh C. Arora, Ph.D. ${ }^{\dagger}$ and Herbert Y. Meltzer, M.D.
}

The effect of clozapine and typical neuroleptic drug treatment on platelet serotonin $2\left(5-\mathrm{HT}_{2}\right)$ binding kinetic constants $\left(K_{d}, B_{\max }\right)$ was studied in schizophrenic patients. Both treatments increased $B_{\max }$ by a comparable amount, indicating increased numbers of 5- $\mathrm{HT}_{2}$ sites, although not all typical neuroleptic drugs were effective in this regard. Clozapine, but not typical neuroleptic drugs, increased $K_{d}$, indicating a lower affinity of the 5- $\mathrm{HT}_{2}$ sites for 5-HT. In a multiple regression model, low $B_{\max }$ at baseline predicted poor outcome on Brief Psychiatric Rating Scale measures in the clozapine-treated patients but not the neuroleptic-treated patients.

[Neuropsychopharmacology 10:109-114, 1994]
KEY WORDS: Clozapine; Serotonin; Schizophrenia; Neuroleptic treatment; Platelet receptor binding

Clozapine has been shown to be an effective antipsychotic drug for the treatment of neuroleptic-resistant schizophrenic patients and to produce fewer extrapyramidal symptoms (Kane et al. 1988; Meltzer 1990). It has been suggested that the ability of clozapine to block central serotonin-2 $\left(5-\mathrm{HT}_{2}\right)$ receptors may contribute to its clinical advantages (see Meltzer 1989, 1991, for reviews).

In vivo, clozapine has been reported to downregulate $5-\mathrm{HT}_{2}$ receptor in rat frontal cortex after acute (Matsubara and Meltzer 1989) and chronic treatment (Reynolds et al., 1983; Lee and Tang 1984; Ellis et al. 1988; Matsubara and Meltzer 1978). This effect has been attributed to its $5-\mathrm{HT}_{2}$ antagonist properties.

From the Laboratory of Biological Psychiatry, Department of Psychiatry, School of Medicine, Case Western Reserve University, Cleveland, Ohio.

Address correspondence to: Herbert Y. Meltzer, M.D., Department of Psychiatry, School of Medicine, Case Western Reserve University, 2040 Abington Road, Cleveland, OH 44106-5000.

${ }^{+}$Deceased, May 1993.

Received March 23, 1993; revised November 9, 1993; accepted November 17, 1993.
Serotonin-2 receptor binding has been studied in the postmortem brains of schizophrenic patients. However, the results are controversial. Increased (Whitaker et al. 1981), decreased (Bennett et al. 1979; Mita et al. 1986; Arora and Meltzer 1991; Laruelle et al. 1991) or normal (Mackay et al. 1978; Owen et al. 1981; Reynolds et al. 1983) $5-\mathrm{HT}_{2}$ binding has been reported in the frontal cortex of neuroleptic-treated schizophrenic patients. Because neuroleptic drugs may downregulate $5-\mathrm{HT}_{2}$ receptors in rodent brain (Andree et al. 1986; Lee and Tang 1984), these results could be influenced by neuroleptic treatment. However, Mita et al. (1986) and Laruelle et al. (1991) did not find any differences between the $5-\mathrm{HT}_{2}$ binding in the frontal cortex of neuroleptic-treated and unmedicated schizophrenic patients. Consistent with the concept of downregulated $5-\mathrm{HT}_{2}$ receptors in schizophrenia, Lee et al. (1992) reported that the hypothermic response following administration of MK-212, a centrally-acting $5-\mathrm{HT}_{1 \mathrm{Cl}}$ $5-\mathrm{HT}_{2}$ agonist, was decreased in schizophrenic patients.

A 5- $\mathrm{HT}_{2}$ receptor with similar pharmacological properties to that of human brain has been identified in human blood platelets (Geaney et al. 1984; Elliott and Kent 1989). Increased 5- $\mathrm{HT}_{2}$ binding was found in the blood platelets of suicidal compared to non-suicidal 
schizophrenic patients and normal controls (Arora and Meltzer 1993). No significant group difference was observed between schizophrenic patients and normal controls (Arora and Meltzer 1993). No significant group difference was observed between schizophrenic patients and normal controls (Arora and Meltzer 1993). Schachter et al. (1985) reported increased $K_{d}$ and $B_{\max }$ of 5- $\mathrm{HT}_{2}$ binding in the blood platelets of neuroleptic(fluphenazine, flupenthixol, clopenthixol, chlorpromazine)-treated schizophrenic patients. We have now studied the effect of chronic clozapine treatment on $5-\mathrm{HT}_{2}$ receptor binding in the blood platelets of schizophrenic patients. In addition, we studied the effect of treatment with typical neuroleptic drugs on platelet $5-\mathrm{HT}_{2}$ receptor binding and compared the results with those from clozapine-treated schizophrenic patients.

\section{METHODS}

All patients were diagnosed according to Research Diagnostic Criteria (RDC) (Spitzer et al. 1978) with data obtained with the Schedule for Affective Disorders and Schizophrenia (Endicott and Spitzer 1978) and all information available from the entire hospital course. Twenty-nine patients ( 21 male, eight female) had not received any psychotic drugs for at least seven days before study. Twenty-five ( 20 male, five female) clozapinetreated patients $(\bar{x} \mathrm{SD}=467 \pm 132 \mathrm{mg} /$ day, range 125 $\mathrm{mg}$ to $900 \mathrm{mg} /$ day) were studied: 20 between 12 and 60 days of treatment, one after 76 days, three after 150 to 200 days, and one for 694 days. Thirty-two (26 male, six female) schizophrenic patients treated with typical neuroleptic drugs were studied. The duration of treatment in 30 patients was 15 to 70 days; one was studied after 240 days and another after 365 days of treatment. The antipsychotic drugs utilized were haloperidol $(n=$ $9)$, thioridazine $(n=7)$, trifluoperazine $(n=3)$, loxapine $(n=4)$, perphenazine $(n=3)$ and fluphenazine $(n=6)$. The mean dose in chlorpromazine equivalents was $540 \pm 113 \mathrm{mg} /$ day.

The mean age of unmedicated, clozapine-treated, and typical neuroleptic-treated patients was $36.1 \pm 8.3$, $34.5 \pm 8.9$, and $34.6 \pm 10.0$ years, respectively. There were no differences in age between the three groups.

All results are mean \pm SD.

\section{Determination of Platelet 5-HT Receptor Binding}

Blood ( $30 \mathrm{ml})$ was drawn into plastic syringes and transferred into plastic tubes containing $1 \%$ ethylenediaminetetraacetic acid in saline as anticoagulant $(1 \mathrm{ml} /$ $9 \mathrm{ml}$ of blood). Platelet-rich plasma was obtained by centrifugation at $600 \times \mathrm{g}$ for 2.5 minutes in a Sorvall GLC-2 centrifuge using a swinging bucket rotor as described earlier (Sahai et al. 1981). Platelet membranes were prepared following the method of Geaney et al. (1984).

Serotonin-2 receptor binding was determined by incubating platelet membranes with ${ }^{3} \mathrm{H}$-lysergic acid diethylamide ( ${ }^{3} \mathrm{H}$-LSD) as described earlier (Arora and Meltzer 1989). Five concentrations of ${ }^{3} \mathrm{H}$-LSD between $0.2 \mathrm{nmol} / \mathrm{L}$ to $4.0 \mathrm{nmol} / \mathrm{L}$ were used in the incubation mixture to determine the apparent dissociation constant $\left(\mathrm{K}_{\mathrm{d}}\right)$ and the maximum number of specific binding sites $\left(\mathrm{B}_{\max }\right)$ by Scatchard analysis. Protein in the platelet membrane preparation was determined by Lowry's method (Lowry et al. 1951). The $K_{d}$ and $B_{\max }$ in 42 normal controls were $0.72 \pm 0.31$ (SD) $\mathrm{nM}$ and $84.6 \pm 24.9$ $\mathrm{fmol} / \mathrm{ng}$ protein (Arora and Meltzer 1993).

The radioactive ${ }^{3} \mathrm{H}$-LSD (sp. act. $79.9 \mathrm{Ci} /$ mmole) was purchased from New England Nuclear (Boston, $\mathrm{MA})$. All of the other chemicals used were of analytical grade quality.

\section{RESULTS}

The kinetic parameters $\left(\mathrm{K}_{\mathrm{d}}\right.$ and $\left.\mathrm{B}_{\max }\right)$ of ${ }^{3} \mathrm{H}$-LSD binding in the blood platelets of unmedicated schizophrenic patients during clozapine treatment or typical neuroleptic treatment are reported in Table 1 . There were no significant differences between $B_{\max }$ and $K_{d}$ of the neuroleptic-withdrawn schizophrenic patients and the normal controls. The correlations between number of days washout and $\mathrm{B}_{\max }$ or $\mathrm{K}_{d}$ were not significant $(r=0.25$ and $r=0.09$, respectively). There were three subjects with washouts of 20 or more days. There was no evidence for lower $B_{\max }$ levels in this group compared to nine patients with washouts of only 7 to 10 days (118 \pm 9 versus $90 \pm 16 \mathrm{fmol} / \mathrm{mg}$ protein). Correlations between $K_{d}$ and $B_{\max }$, and the number of days of treatment, or the doses of clozapine or typical neuroleptic drugs in chlorpromazine equivalents, were not signifcant (data not presented). Hence, the data from different days and different doses were combined and reported in Table 1. Univariate analyses of variance indicated significant group difference in $\mathrm{K}_{\mathrm{d}}$ and $\mathrm{B}_{\max }$ of ${ }^{3} \mathrm{H}$-LSD binding. $B_{\max }$ was significantly increased in the clozapine- and typical neuroleptic-treated patients compared to the drug-free patients. However, there was no difference in $B_{\max }$ between the two drug-treated groups. $K_{d}$ was also significantly increased during clozapine treatment but not during typical neuroleptic treatment. Further analysis of individual drug treatment in the typical neuroleptic group indicated that a significant increase in $B_{\max }$ was observed only in the thioridazine- $(n=7)$, loxapine- $(n=4)$ and fluphenazine$(n=6)$ treated patients. There was a trend for increase 
Table 1. Effect of Clozapine and Typical Neuroleptics on ${ }^{3} \mathrm{H}$-LSD Binding in the Blood Platelets of Schizophrenic Patients

\begin{tabular}{lccc}
\hline Treatment & $\boldsymbol{n}$ & $\begin{array}{c}\mathbf{K}_{\mathbf{d}} \\
\text { (nmol/L) }\end{array}$ & $\begin{array}{c}\mathbf{B}_{\max } \\
\text { (fmols/mg/protein) }\end{array}$ \\
\hline No treatment & 29 & $0.68 \pm 0.32$ & $97.8 \pm 30.07$ \\
Clozapine & 25 & $1.19 \pm 0.64^{\star}$ & $177.6 \pm 70.0^{\star}$ \\
Typical & & & \\
neuroleptics & 32 & $0.80 \pm 0.36$ & $140.4 \pm 52.0^{\star}$ \\
$\quad$ Haloperidol & 9 & $0.71 \pm 0.42$ & $117.7 \pm 41.4^{\star \star}$ \\
Thioridazine & 7 & $0.85 \pm 0.23$ & $172.6 \pm 54.8^{\star}$ \\
Fluphenazine & 6 & $0.89 \pm 0.52$ & $151.7 \pm 27.6^{\star}$ \\
Loxapine & 4 & $0.72 \pm 0.20$ & $181.8 \pm 69.2^{\star}$ \\
Perphenazine & 3 & $0.97 \pm 0.49$ & $98.4 \pm 14.5$ \\
$\quad$ Trifluoperazine & 3 & $0.67 \pm 0.25$ & $97.9 \pm 39.9$ \\
\hline
\end{tabular}

* Significantly higher than no treatment group.

$\star t=1.57 ; p<0.05>0.1$.

Data are expressed as \pm SD.

in $\mathrm{B}_{\max }$ in the haloperidol-treated patients $(n=9 ; p<$ $.1>.05)$. There was no suggestion of a difference between untreated and trifluoperazine $(n=3)$ - and perphenazine $(n=3)$-treated patients.

We also studied 11 patients pre- and post-clozapine treatment and nine patients pre- and post-typical neuroleptic treatment (thioridazine, $n=4$; loxapine, $n=$ 2; haloperidol, trifluoperazine and perphenazine, each one patient). The mean duration of treatment was $39.6 \pm 14.2$ days. The mean dose of neuroleptic in chlorpromazine equivalents was $643 \pm 169 \mathrm{mg} /$ day. The results are reported in Fig. 1 and Fig. 2, respectively. As evident from Figure 1, we again observed significant increases in $K_{d}$ and $B_{\max }$ following clozapine treatment. Similarly, $B_{\max }$, but not $K_{d}$, increased during treatment with typical neuroleptic drugs (Fig. 2).

There were no significant correlations between change in $B_{\max }$ or $K_{d}$ and changes in BPRS Total and Positive symptoms at 6 weeks. However, there was a trend for a significant positive correlation between change in $B_{\max }$ and change in negative symptoms ( $r h o=.585 ; p=.058$ ) after 6 weeks of clozapine treatment. There were also significant negative correlations between $\Delta \mathrm{B}_{\max }$ and $\Delta$ BPRS Total (rho $=-0.79 ; n=$ $7 ; p=.04$ ) and $\Delta$ BPRS Positive ( $r$ ro $=-0.81 ; n=7$, $p=.03$ ) for the typical neuroleptic-treated patients.

In a multiple regression model in which BPRS Total at 6 weeks of clozapine treatment was predicted from Baseline BPRS Total, pretreatment $K_{d}$ and $B_{\max }, B_{\max }$ (standard estimate $=-0.60, p=.01, d f=1.10)$ significantly predicted BPRS Total at 6 weeks. Pretreatment $B_{\max }$ also was inversely related to outcome as indicated by BPRS Positive Symptoms $(p=.005)$. There were no significant relationships between post-treatment BPRS negative symptoms and $B_{\max }$ or $K_{d}$ for the clozapine-treated patients in the multivariate model. Similarly, there were no relationships between pretreatment or post-treatment $B_{\max }$ or $K_{d}$ and BPRS Total, Positive, or Negative symptoms in the neuroleptictreated patients.

\section{DISCUSSION}

The major finding in this study is that clozapine treatment increased $K_{d}$ and $B_{\max }$ of $5-\mathrm{HT}_{2}$ receptor binding in the blood platelets of schizophrenic patients, whereas typical neuroleptic treatment increased only the $B_{\max }$ of $5-\mathrm{HT}_{2}$ binding. No difference in $\mathrm{K}_{\mathrm{d}}$ was observed between pre- and post-typical neuroleptic treatment. There was a nearly significant positive correlation $(p=$ .058) between the change in $B_{\max }$ during clozapine treatment and the change in negative symptoms of schizophrenic patients. Furthermore, there was also a suggestion that low baseline $B_{\max }$ predicts a poor response to clozapine and that the increase in $B_{\max }$ dur-

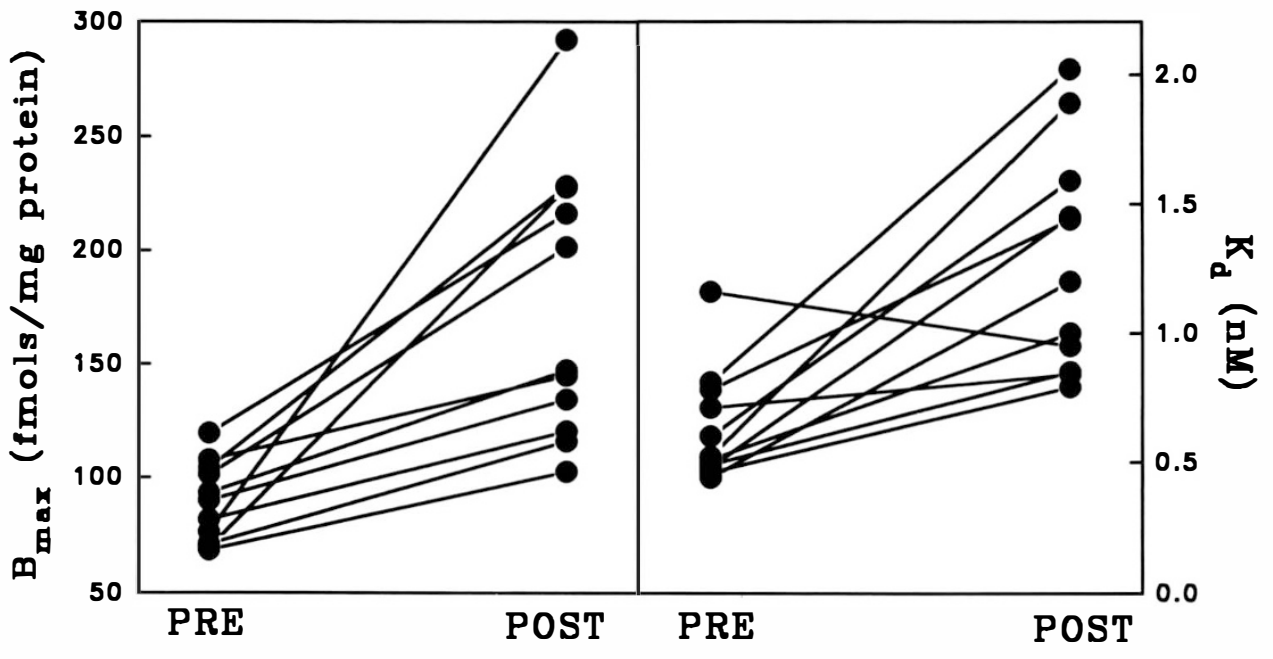

Figure 1. Effect of clozapine treatment on $\mathrm{K}_{\mathrm{d}}$ and $\mathrm{B}_{\max }$ of ${ }^{3} \mathrm{H}$-LSD binding in the blood platelets of 11 schizophrenic patients. $K_{d}$ increased from $.63 \pm .22 \mathrm{nM}$ to $1.27 \pm .43$ $(t=4.45 ; p<.005 ;$ paired $t$-test). $B_{\max }$ increased from $89.5 \pm 17.3 \mathrm{fmol} / \mathrm{mg}$ protein to $175.5 \pm 60.6 \mathrm{fmol} / \mathrm{mg}$ protein $(t=4.78 ; p<.005$; paired $t$-test). 


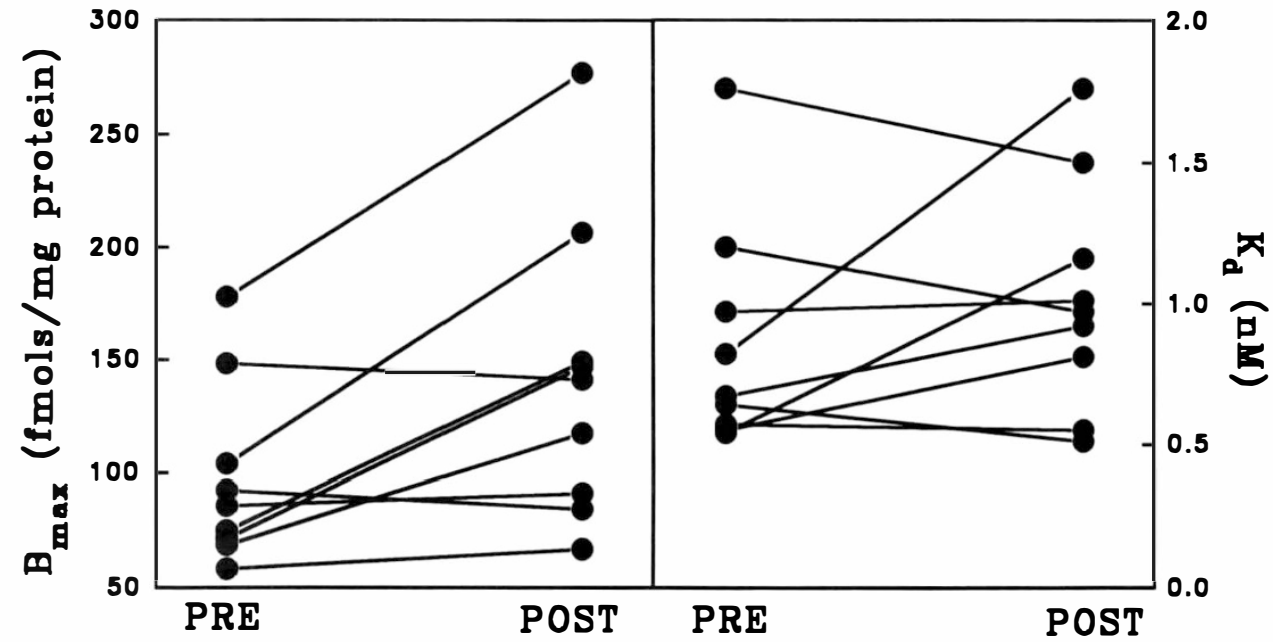

Figure 2. Effect of typical neuroleptic treatment on $\mathrm{K}_{\mathrm{d}}$ and $\mathrm{B}_{\max }$ of ${ }^{3} \mathrm{H}$-LSD binding in the blood platelets of nine schizophrenic patients. $K_{d}$ did not significantly change $(.86 \pm \mathrm{nmol} / \mathrm{L}$ prior to treatment versus $1.02 \pm .41$ $\mathrm{nmol} / \mathrm{L} ; t=1.21 ; p=\mathrm{NS}$; paired $t$-test). $B_{\max }$ increased from $97.9 \pm 40.0 \mathrm{fmol} / \mathrm{mg}$ protein to $142.2 \pm 65.8 \mathrm{fmol} / \mathrm{mg}$ protein $(t=2.93 ; p<.02$; paired $t$-test). ing neuroleptic treatment was associated with less improvement.

The possibility that the washout from prior neuroleptic treatment was inadequate was considered. The mean duration was 12.0 days, which is approximately two half-lives of human blood platelets, so that fully $75 \%$ of the platelets should have been replaced at the time of study. Had there been a residual effect of prior neuroleptic treatment, an increase in $B_{\max }$ compared to normal controls would have been found, but this was not observed. We also found no correlation between $B_{\max }$ or $K_{d}$ and the duration of washout. Therefore, we believe the results reported here are not significantly affected by prior neuroleptic treatment.

The increase in $B_{\max }$ in platelets during clozapine treatment and treatment with some neuroleptic drugs is contrary to what has been observed in brain (see below) with these drugs but is consistent with the usual effect of antagonists to upregulate the number of binding sites.

The $K_{d}$ and $B_{\max }$ values of platelet $5-\mathrm{HT}_{2}$ receptor binding in normal controls and schizophrenic patients reported here are similar to those reported earlier in another sample (Arora and Meltzer 1989; 1993). Increased $5-\mathrm{HT}_{2}$ binding following neuroleptic treatment (present study) is consistent with the observations of increased platelet function believed to be mediated by $5-\mathrm{HT}_{2}$ receptors, (i.e., platelet aggregation response to $5-\mathrm{HT}_{2}$ during chlorpromazine treatment [Oppenheim et al. 1980]) and chlorpromazine, fluphenazine, flupenthixol, trifluoperazine, or haloperidol treatment of schizophrenic patients (Orr et al. 1981). A significant correlation has been previously reported between $5-\mathrm{HT}_{2}$ receptor binding in human blood platelets and the 5-HT-amplified aggregation response (McBride et al. 1987). Animal studies also indicated increased platelet $5-\mathrm{HT}_{2}$ receptor function following chlorpromazine treatment as evidenced by increased aggregation re- sponse to 5-HT in the blood platelets of chlorpromazine-treated rabbits (Baldacci et al. 1980). Increased $5-\mathrm{HT}_{2}$ binding has also been reported in rat blood platelets following chronic treatment with ritanserin, which like clozapine is a potent $5-\mathrm{HT}_{2}$ receptor antagonist (Twist et al. 1990). Although these results with ritanserin would suggest that blockade of $5-\mathrm{HT}_{2}$ receptor accounts for the upregulation of the platelet $5-\mathrm{HT}_{2}$ binding sites, some of the typical neuroleptic drugs that cause upregulation have a low affinity for $5-\mathrm{HT}_{2}$ receptors (e.g., fluphenazine and thioridazine [Meltzer et al., 1989). Thus, the biological basis for the changes in $B_{\max }$ remain obscure.

The results reported here with typical neuroleptic drugs are in partial agreement with those reported by Schachter et al. (1985) who reported an increase in $K_{d}$ as well as $B_{\max }$ of $5-\mathrm{HT}_{2}$ receptor binding in schizophrenic patients receiving depot neuroleptic treatment. Schachter et al. (1985) speculated that neuroleptic-induced increases in $K_{d}$ may be due to drug retension during preparation of platelet membranes. The procedure of Geaney et al. (1984) for preparing platelet membranes was utilized both in this study and in that of Schachter et al. (1985). Furthermore, platelet membranes were prepared the same way for both typicaland atypical (clozapine)-antipsychotic drug treated patients. Because relatively small numbers of subjects were studied with each of the typical neuroleptic drugs, it is not possible to draw furm conclusions about the presence of qualitative differences among them. It would appear, however, that the high potency drugs such as haloperidol, fluphenazine, perphenazine, and trifluoperazine, are less effective than the low potency neuroleptic, thioridazine, or the clozapine analog, loxapine with regard to increasing $B_{\max }$. The minimal effects of the high potency agents on $B_{\max }$ or $K_{d}$ suggests that the $D_{2}$ dopamine receptor blocking effect of these agents is not important to this effect. Because loxapine, 
a potent 5- $\mathrm{HT}_{2}$ antagonist (Meltzer et al. 1989), did not appear to increase $K_{d}$, the ability of clozapine to increase $K_{d}$ is not necessarily related to its affinity for $5-\mathrm{HT}_{2}$ receptors.

The effects of typical neuroleptics on $5-\mathrm{HT}_{2}$ binding in rodent brain are controversial. Wilmot and Szczepanik (1989) and others (Lee and Tang 1984; Peroutka and Snyder 1980) did not report any effect of chronic haloperidol or chlorpromazine treatment on $5-\mathrm{HT}_{2}$ binding in rat brain, whereas Lee and Tang (1984) and Andree et al. (1986) reported significantly decreased $5-\mathrm{HT}_{2}$ binding in rat frontal cortex following chronic neuroleptic treatment with chlorpromazine, thioridazine, loxapine, or clozapine. The extent of the decrease in $B_{\max }$ produced by different neuroleptics was variable; chlorpromazine (Andree et al. 1986) produced the strongest effect. Clozapine administration has also been reported to rapidly and markedly downregulate $5-\mathrm{HT}_{2}$ receptors in rat frontal cortex (Matsubara and Meltzer 1989).

Human studies also indicated no significant difference in 5- $\mathrm{HT}_{2}$ binding in the frontal cortex of neuroleptic-treated and drug-free schizophrenic patients (Mita et al. 1986). We (Arora and Meltzer 1991) studied 5- $\mathrm{HT}_{2}$ binding in the frontal cortex of neuroleptic-treated schizophrenic patients and could find no evidence that neuroleptics downregulate $5-\mathrm{HT}_{2}$ binding in humans. These apparent differences in the effect of neuroleptic and clozapine treatment in platelet $5-\mathrm{HT}_{2}$ binding and animal brain $5-\mathrm{HT}_{2}$ binding studies suggests that there are different regulatory mechanisms governing platelet and neuronal 5- $\mathrm{HT}_{2}$ receptors and that blood platelets may not be a good model for the effect of antipsychotic drugs on brain $5-\mathrm{HT}_{2}$ receptors.

Similar discrepancies between platelet and brain 5- $\mathrm{HT}_{2}$ binding sites have been reported with tricyclic antidepressants. They have been shown to downregulate $5-\mathrm{HT}_{2}$ receptors in rat brain in some but not all studies (see Twist et al. 1990; Willner 1985 for review). Increased $5-\mathrm{HT}_{2}$ binding has been reported in blood platelets in normal volunteers following chronic desipramine treatment (Cowen et al. 1986), whereas decreased $5-\mathrm{HT}_{2}$ binding has been reported in the blood platelets of depressed patients following tricyclic antidepressant treatment (Biegon et al. 1987). There is no evidence that clozapine or typical neuroleptic drugs lead to increased $5-\mathrm{HT}_{2}$ receptor-mediated activity because the cortisol response to 5-hydroxtryptophan (5-HT) is blocked by clozapine treatment(Meltzer, H.Y., in preparation).

The finding that low $B_{\max }$ predicted poor response to clozapine at 6 weeks is intriguing but must be verified in an independent sample. If this is a reliable finding, it might be helpful in identifying good candidates for clozapine

the increase in platelet $5-\mathrm{HT}_{2}$ binding sites reflects a similar increase in brain 5- $\mathrm{HT}_{2}$ binding sites for clozapine and some typical neuroleptic drugs. Similar considerations apply to the increase in platelet $K_{d}$ and possible effect of clozapine on the $\mathrm{K}_{\mathrm{d}}$ of the brain $5-\mathrm{HT}_{2}$ receptors.

Further studies of the function of the $5-\mathrm{HT}_{2}$ receptor in clozapine-treated or typical neuroleptic-treated patients are indicated to determine if the results reported here influence the effects of 5-HT on platelet shape change or platelet aggregation. To our knowledge, no platelet-related abnormalities have been reported in patients treated with these drugs that could be ascribed to changes in $B_{\max }$ or $K_{d}$, or both.

In summary, treatment of schizophrenic patients with clozapine or some typical neuroleptic drugs decreases the number of $5-\mathrm{HT}_{2}$ sites in blood platelets. These results are contrary to what has been observed in rodent brain and may also differ from the effects of these drugs on brain $5-\mathrm{HT}_{2}$ receptors during clinical treatment. However, there was some evidence for the ability of baseline $5-\mathrm{HT}_{2}$ binding sites $\left(\mathrm{B}_{\max }\right)$ to predict response to clozapine. Because of the small number of patients in this study $(n=11)$, further study with more patients is needed to confirm these results.

\section{ACKNOWLEDGMENT}

The research reported was supported in part by USPHS MH 41684, GCRC MO1RR00080, the Department of Veterans Affairs and grants from the Elisabeth Severance Prentiss and John Pascal Sawyer Foundations. H.Y.M. is the recipient of a USPHS Research Career Scientist Award MH 47808. The secretarial assistance of Ms. Lee Mason is greatly appreciated.

\section{NOTE ADDED IN PROOF}

Two recent studies have found that the binding characteristics of the $5-\mathrm{HT}_{2}$ receptor in main cortex synaptosomes and platelet membranes in man (Andres et al. 1993) and pigs (Ostrowitzki et al. 1993) were correlated and were suggested to be similarly regulated: Andres AH, Rao ML, Ostrowitzki S, and Entzian W (1993): Human brain cortex and platelet serotonin-2-receptor binding properties and their regulation by endogenous serotonin. Life Sci 52:313-321. Ostrowitzki S, Rao ML, Rédei J, and Andres AH (1993). Concurrence of cortex and platelet serotonin-2-receptor binding characteristics in the individual and the putative regulation by serotonin. J Neural Transm (Gen Sect) 93:27-35.

\section{REFERENCES}

Andree TH, Mikuni M, Tong CY, Koenig JI, Meltzer HY (1986): Differential effect of subchronic treatment with various neuroleptic agents on serotonin 2 receptors in rat cerebral cortex. J Neurochem 46:191-197

Arora RC, Meltzer HY (1989): Increased serotonin 2 (5-HT2) receptor binding as measured by ${ }^{3} \mathrm{H}$-lysergic acid diethylamide ( ${ }^{3} \mathrm{H}$-LSD) in the blood platelets of depressed patients. Life Sci 44:725-734 
Arora RC, Meltzer HY (1991): Serotonin 2 (5-HT2) receptor binding in the frontal cortex of schizophrenic patients. J Neural Transm 85:19-29

Arora RC, Meltzer HY (1993): Serotonin (5-HT2) receptor binding in blood platelets of schizophrenic patients. Psychiatry Res 47:111-120

Baldacci M, Baldacci M, Bergel TD, Born GVR, Hickman M (1980): Increases in aggregation by and uptake of 5-hydroxytryptamine with platelets from rabbits treated with chlorpromazine. Br J Pharmacol 69:113-118

Bennett JP Jr, Enna SJ, Bylund DB, Gillin JC, Wyatt RJ, Snyder SH (1979): Neurotransmitter receptors in frontal cortex of schizophrenia. Arch Gen Psychiatry 36:927-934

Biegon A, Weizman A, Korp L, Ram A, Tiano S, Wolff M (1987): Serotonin 5- $\mathrm{HT}_{2}$ receptor binding on the blood platelets-A peripheral marker for depression. Life Sci 41:2485-2492

Cowen PJ, Charig EM, Fraser S, Elliott JM (1987): Platelet 5-HT receptor binding during depressive illness and tricyclic antidepressant treatment. J Aff Dis 13:45-50

Cowen PJ, Geaney DP, Schachter M, Green AR, Elliott JM (1986): Desipramine treatment in normal subjects: Effects on neuroendocrine responses to tryptophan and on platelet serotonin (5-HT)-related receptors. Arch Gen Psychiatry 43:61-67

Elliott JM, Kent A (1989): Comparison of $\left({ }^{125}\right.$ I)iodo-lysergic acid diethylamide binding in human frontal cortex and platelet tissue. J Neurochem 53:191-196

Ellis DB, Szczepanik AM, Wilmot CA (1988): Acute and chronic effects of HP370 and clozapine on dopamine $\mathrm{D}_{2}$ and serotonin-2 receptors: rat brain autoradiographic studies. Proc Biochem Soc Trans 17:166-167

Endicott RK, Spitzer R(1978): A diagnostic interview: A schedule for affective disorders and schizophrenia. Arch Gen Psychiatry 35:837-844

Geaney DP, Schachter M, Elliott JM, Grahame-Smith DG (1984): Characterization of ${ }^{3} \mathrm{H}$-lysergic acid diethylamide binding to a 5-hydroxytryptamine receptor on human platelet membranes. Eur J Pharmacol 97:87-93

Kane J, Honigfeld G, Singer J, Meltzer HY, Clozaril Collaborative Study Group (1988): Clozapine for the treatmentresistant schizophrenic: A double-blind comparison with chlorpromazine. Arch Gen Psychiatry 45:789-796

Laruelle M, Toti R, Abi-Darghan A, Weinberger DR, Kleinman JE (1991): Postmortem study of serotonergic markers in schizophrenia. Biol Psychiatry 29:715 S

Lee HS, Bastani B, Friedman L, Ramirez L, Meltzer HY (1992): Effect of the serotonin agonist, MK-212, on body temperature in schizophrenia. Biol Psychiatry 31:460-470

Lee T, Tang SW (1984): Loxapine and clozapine decrease serotonin $\left(S_{2}\right)$ but do not elevate dopamine $\left(D_{2}\right)$ receptor numbers in the rat brain. Psychiatry Res 12:277-285

Lowry O, Rosebrough NJ, Farr AL, Randall RJ (1951): Protein measurement with the Folin phenyl reagent. J Biol Chem 193:265-275

Mackay AVP, Davies P, Dewar AJ, YatesCM (1978): Regional distribution of enzymes associated with neurotransmission by monoamine, acetylcholine and GABA in the human brain. J Neurochem 30:827-839

Matsubara S, Meltzer HY (1989): Effect of typical and atypical antipsychotic drugs on $5-\mathrm{HT}_{2}$ receptor density in rat cerebral cortex. Life Sci 45:1397-1406
McBride PA, Mann JJ, Polley MJ, Wiley AJ, Sweeney JA (1987): Assessment of binding indices and physiological responsiveness of the $5-\mathrm{HT}_{2}$ receptor on human platelets. Life Sci 40:1799-1809

Meltzer HY (1989): Clinical studies on the mechanism of action of clozapine: the dopamine-serotonin hypothesis of schizophrenia. Psychopharmacology 99:S18-S27

Meltzer HY (1990): The role of serotonin in the action of atypical antipsychotic drugs. Psychiatric Ann 20:(10): 571-579

Meltzer HY (1991): The mechanism of action of novel antipsychotic drugs. Schiz Bull 17:263-287

Meltzer HY, Matsubara S, Lee J-C (1989): Classification of typical and atypical antipsychotic drugs on the basis of dopamine D-1, D-2 and serotonin 2 pKi values. J Pharmacol Exp Ther 251:238-246

Mita T, Hanada S, Nishino N, Kuno T, Nakai H, Yamadori T, Mizoi Y, Tanaka C (1986): Decreased serotonin $S_{2}$ and increased dopamine $D_{2}$ receptor in chronic schizophrenics. Biol Psychiatry 21:1407-1414

Oppenheim B, Hefez A, Youdim MBH (1980): Serotonin receptor site in human platelets from control and chlorpromazine-treated subjects. Prog Biochem Pharmacol 16:119-132

Orr MW, Knox JM, Allen R, Gelder MG, Grahame-Smith DG (1981): The effects of neuroleptic drugs on 5-hydroxytryptamine-induced platelet aggregation in schizophrenic patients. Br J Clin Pharmacol 11:255-259

Owen F, Cross AJ, Crow TJ, Lofthouse R, Poulter M (1981): Neurotransmitter receptors in brain in schizophrenia. Acta Psychiatr Scand 63:20-28

Peroutka SJ, Snyder SH (1980): Chronic antidepressant treatment lowers spiroperidol-labeled serotonin receptor bindings. Science 210:88-90

Reynolds GP, Garrett NJ, Rupniak N, Jenner P, Marsden CD (1983): Chronic clozapine treatment of rats downregulates cortical 5- $\mathrm{HT}_{2}$ receptors. Eur J Pharmacol 89:325326

Sahai S, Arora RC, Meltzer HY (1981): Platelet monoamine oxidase 1: effect of temperature, coagulant and centrifugation technique. Biol Psychiatry 16:1077-1083

Schachter M, Geaney DP, Grahame-Smith DG, Cowen PJ, Elliott JM (1985): Increased platelet membrane $\left[{ }^{3} \mathrm{H}\right] \mathrm{LSD}$ binding in patients on chronic neuroleptic treatment. $\mathrm{Br}$ J Clin Pharmacol 19:453-457

Spitzer RL, Endicott RL, Robbins E (1978): Research Diagnostic Criteria: Rationale and reliability. Arch Gen Psychiatry 35:773-792

Twist EC, Mitchell S, Brazell C, Stahl SM, Campbell IC (1990): $5-\mathrm{HT}_{2}$ receptor changes in rat cortex and platelets following chronic ritanserin and clorgyline administration. Biochem Pharmacol 39:161-166

Whitaker PJ, Crow JT, Ferrier IN (1981): Triatiated LSD binding in frontal cortex in schizophrenia. Arch Gen Psychiatry 38:278-280

Willner P (1985): Antidepressants and serotonergic neurotransmission: An integrative review. Psychopharmacology 85:387-404

Wilmot CA, Szczepanik AM (1989): Effects of acute and chronic treatment with clozapine and haloperidol on serotonin $\left(5-\mathrm{HT}_{2}\right)$ and dopamine $\left(\mathrm{D}_{2}\right)$ receptors in the rat brain. Brain Res 487:288-298 